\title{
FLAVONOID CONSTITUENTS OF Reaumuria hirtella.
}

\author{
(Received : 21.3. 2014) \\ By \\ A.E.Abozeed \\ Medicinal and Aromatic Plants, Desert Research Center, El-Matarya, Cairo, Egypt
}

\begin{abstract}
The present study aimed to investigate the total flavonoid compounds from the aerial parts and the roots of Reaumuria hirtella collected at different seasons of (2012-2013) from Ageba region. Also, it aimed to isolate and identify the flavonoid compounds from the aerial parts only using chromatographic and spectroscopic analysis: UV, MS, ${ }^{1} \mathrm{H}-\mathrm{NMR}$ and ${ }^{13} \mathrm{C}-\mathrm{NMR}$. In addition, these compounds were determined spectrophotometrically and calculated as kaempferol. The results showed that the total flavonoid contents of the aerial parts were higher generally than that of the roots. The spectroscopic analysis revealed the presence of seven flavonoid compounds: kaempferol, kaempferol3-O- $\alpha$-1-rhamnoside, kaempferol 7-O-diglucoside, quercetin, quercetin-3-O- rutinoside (rutin), quercetin-3-rhamnoside and quercetin -3-O-glucoside and one phenolic compound as ferulic acid.
\end{abstract}

Key words: flavonoids, phenolic acids, Reaumuria hirtella.

\section{INTRODUCTION}

The genus Reaumuria consists of 12 species belongs to the family Tamaricaceae and distributed in the deserts of Northern Africa, Asia and Southern Europe (Yang and Gaskin, 2006).

A sulphated flavonol has been isolated from the leaves of $R$. mucronata and identified as kaempferol 3,7-disulphate (Nawwar et al., 1977).

Flavonol, kaempferol and quercetin, and their glycosides are major flavonoids, and also methylated flavonols, rhamnazin, rhamnetin, rhamnocitrin, kaempferide, tamarixetin, kaempferol 7,4'-dimethyl ether and dillenetin, and their glycosides are found in some species of the Tamaricaceae (El Sissi et al., 1973; Nawwar et al., 1975 and 1984; Wang et al., 2009 and La et al., 2011 ). Flavonols frequently occur as sulphates in the Tamaricaceae (Harborne, 1975; Saleh et al., 1975; El Ansari et al., 1976 and Tomás-Barberán et al., 1990 ).

Ten flavonoids were isolated from the aerial parts of Reaumuria soongarica growing in the deserts of Mongolia (Tsukasa, et al., 2012).

In this paper, we describe the isolation and identification of flavonoids and their chemical properties from the aerial parts of Reaumuria hirtella growing in Ageba region (northern coastal region).

\section{MATERIALS AND METHODS \\ 2.1. Materials \\ 2.1.1. Source of plants}

The fresh aerial parts and roots of Reaumuria hirtella were collected seasonally from Ageba region (Northern coastal region) during the period of investigation. The plant materials were cleaned, dried in an electric oven at $50^{\circ} \mathrm{C}$ and ground to fine powder and then kept for analysis.

\subsubsection{Solvents}

Ethyl alcohol, n-butanol, acetic acid, were obtained from petroleum ether $\left(40-60^{\circ} \mathrm{c}\right)$, ether, chloroform and ethyl acetate.

\subsubsection{Reagents}

Sodium methoxide solution $(2.5 \mathrm{ml}$ was added cautiously to $100 \mathrm{ml}$ dry methanol), sodium acetate, boric acid, hydrochloric acid (50 $\mathrm{ml}$ were mixed with $100 \mathrm{ml}$ water) and aluminum chloride solution (96 gm anhydrous aluminum chloride in $1 \mathrm{~L}$ ethanol).

\subsubsection{Solvent systems}

1. $\mathrm{n}$. butanol-acetic acid-water $(4: 1: 5 \mathrm{v} / \mathrm{v} / \mathrm{v})$

2. Acetic acid-water $(15: 85 \mathrm{v} / \mathrm{v})$

\subsubsection{Preparation of flavonoids extract}

The dried aerial parts of Reaumuria hirtella were ground to fine powder and extracted with $70 \%$ aqueous $\mathrm{MeOH}$ several times, and evaporated under reduced pressure. The concentrated aqueous extract was fractionated 
successively using Soxhelt apparatus, according to Lee et al., (2004).

\subsection{Methods}

\subsubsection{Quantitative estimation of the total flavonoids}

Total flavonoids were estimated according to the method described by (Karawya and Aboutable, 1982). The flavonoid content was calculated as kaempferol.

Two grams of powder air-dried material, accurately weighed were defatted using petroleum ether $\left(40-60{ }^{\circ} \mathrm{C}\right)$ and extracted with $95 \%$ ethanol till exhaustion. The ethanolic extract was adjusted to $50 \mathrm{ml}$. Five $\mathrm{ml}$ were treated under calebration curve, three determinations were carried out for each sample with reference to the standard curve, the corresponding amounts of kaempferol were found out.

\subsubsection{Calibration curve}

Different aliquots of ethanolic solution of kaempferol equivalent to $5-200 \mu \mathrm{g}$ were separately introduced into test tubes, evaporated till dryness on a hot water bath $\left(40-50{ }^{\circ} \mathrm{C}\right)$. Five $\mathrm{ml}$ of $0.1 \mathrm{M}$ aluminium chloride reagent were added. The absorbance of the color developed was measured at $\lambda$ Max $=266 \mathrm{~nm}$ against a blank. Three determinations for each concentration of standard solution were carried out .

\subsection{Chromatographic analysis}

The concentrated aqueous extract was subjected to two dimensional paper chromatography technique using the solvent system n- butanol: acetic acid: water $(4: 1: 5$, $\mathrm{v} / \mathrm{v} / \mathrm{v}$ ) and acetic acid: water 15:85, respectively. The developed chromatograms were air dried and examined under ultraviolet light. Elution started with benzene and the polarity was increased gradually by the addition of proportion of ether $(10 \%, 20 \%$ and 30\%) followed by chloroform, ethyl acetate and methanol solvents in the same trend. The received fractions were evaporated and similar fractions were collected together, evaporated and subjected to paper chromatography.

Preparative paper chromatography was applied on Whatmann No.3 paper chromatography using the solvent system $\mathrm{AcOH}-15 \%$ (Anderson and Sowers, 1998), repreparative chromatography was applied on thin layer chromatography (TLC). The separated flavonoids and phenolic acids were purified on a Sephadex LH-20 column using methanol/water system.

\subsection{Physical analysis}

\subsubsection{Ultraviolet spectrophotometry (UV)}

The purified material (after passing through Sephadex LH-20) was dissolved in pure methanol then subjected to UV spectrophotometric measurements in quartz cavette (4ml capacity, $1 \mathrm{~cm}$ thick) using Schimadzu UV 240 spectrophotometer. In the case of flavonoids, $\mathrm{AlCl}_{3} / \mathrm{HCl}, \mathrm{NaOAc} / \mathrm{H}_{3} \mathrm{BO}_{3}$ and $\mathrm{NaOMe}$ reagents were separately added to the solution, and UV measurements were then carried out (Mabry et al., 1970) .

\subsection{2. ${ }^{1} \mathrm{H}$-and ${ }^{13} \mathrm{C}$ - Nuclear magnetic resonance} (NMR)

${ }^{1} \mathrm{H}$ - and ${ }^{13} \mathrm{C}-\mathrm{NMR}$ are the most efficient method for identification and elucidation of the structure of various types of flavonoids. Chemical shift in ppm varies according to the proton and/or carbon position in the flavonoids nucleus, thus offering good criteria for structure elucidation. The type and position of the anomeric sugar proton, its "J" value in $\mathrm{Hz}$ are good signs for confirming the chemical structure (Mabry et al., 1970).

The NMR measurement was carried out on A Jeol EX-270 NMR spectrometer apparatus (270 $\mathrm{MHz}$ for ${ }^{1} \mathrm{H}$ - NMR and $67.5 \mathrm{MHz}$ for ${ }^{13} \mathrm{C}$ NMR).

\subsubsection{Mass spectrometry (MS)}

The isolated purified compounds were subjected in most cases to fast atom bombardment (positive and negative) mass spectrometric analysis. (FAB - MS).

* Some other compounds were subjected to electron ionisation and/or chemical ionization mass spectrometric analysis (EL, CL-MS).

* The spectra were conducted using mass spectrometer varian Mat 711, Finnigan SSQ 7000 and MM7070E (Mabry et al., 1970).

\subsection{Chemical reactions}

Analysis to determine the nature of aglycone and sugar was carried out according to standard procedures performed by (Harbone et al., 1975).

\subsubsection{Controlled (Mild) acid hydrolysis}

A known weight of the purified compound was subjected to mild acid hydrolysis in aqueous $\mathrm{HCl}(0.1 \mathrm{~N})$ at $100^{\circ} \mathrm{C}$ for 15 minutes. The reaction mixture was examined at definite intervals by comparative paper chromatography (CoPC) for tracing any intermediate that might be released during the course of hydrolysis.

2.5.2 Complete (Normal) acid hydrolysis

A known weight of the flavonoid material 
under investigation was subjected to acid hydrolysis in either $2 \mathrm{~N} \mathrm{HCl}$ at $100^{\circ} \mathrm{C}$ for 2 hours or in $2 \mathrm{~N} \mathrm{HCl}$ in aqueous $\mathrm{MeOH}(1: 1 \mathrm{v} / \mathrm{v})$ in vacuum.

The obtained hydrolysate in both reactions was then extracted with ethyl acetate. The received AcOEt extract was washed with $\mathrm{H}_{2} \mathrm{O}$ twice, concentrated under vaccum and subjected to (CoPC) using authentic reference markers. The remaining aqueous layer was then freed from acid through extraction with $20 \% \mathrm{~N}$-methyl dioctylamine in $\mathrm{CHCl}_{3}$ and subjected to (CoPC) using authentic sugars as reference markers.

\subsubsection{Enzymatic hydrolysis}

The flavonoid glycosides were enzymaticaly hydrolysed through an enzyme which corresponds to the type of the sugar attaching the compound and the obtained aglycone was tested chromatographically with an authentic sample according to the following formula

Flavonoid glycoside $\stackrel{\beta \text {-glycosidase }}{\longrightarrow}$ aglycon + lucose

One $\mathrm{mg}$ of the compound was dissolved in $2 \mathrm{ml}$ of 0.05 acetate buffer $\mathrm{pH}_{5}$ with $1 \mathrm{mg}$ of the powdered $\beta-$ glycosidase and the mixture was allowed to stand for over night at $37^{\circ} \mathrm{C}$. The hydrolysate was subjected to CoPC against flavonoid authentic markers. Also, the sugar moieties were detected using authentic sugars markers.

\section{RESULTS AND DISCUSSIONS \\ 3.1. Determination of the total flavonoids}

The total flavonoids of the aerial parts and the roots of Reaumuria hirtella at different seasons are given in Table (1). The results indicated that the total flavonoids of the aerial parts were higher than in the roots. Also, it showed that the total flavonoids reached its maximum value of $2.08 \%$ in the aerial parts

Table (1): Total flavonoids of the aerial parts and roots of $R$. hirtella.

\begin{tabular}{|l|c|c|}
\hline \multirow{2}{*}{ Seasons } & \multicolumn{2}{|c|}{ Total flavonoids \% (g/100g. Dry wt.) } \\
\cline { 2 - 3 } & Aerial parts & Roots \\
\hline Winter & 2.08 & 0.32 \\
\hline Spring & 2.02 & 0.33 \\
\hline Summer & 1.58 & 0.29 \\
\hline Autumn & 1.62 & 0.23 \\
\hline
\end{tabular}

during winter and its maximum value of (0.33) in the roots during spring.

\subsection{Investigation of phenolic compounds}

Seven flavonoids and one phenolic compound were isolated, purified by Sephadex LH-20 column, PC and TLC chromatography and identified through UV shift reagents, ${ }^{1} \mathrm{H}$ and ${ }^{13} \mathrm{C}$ - NMR. These compounds were named $\mathrm{F}_{1}-\mathrm{F}_{7}$ and $\mathrm{P}_{1}$

\subsubsection{Kaempferol}

The compound $\mathrm{F}_{1}$ was obtained as yellow crystals, soluble in methanol, m.p.227oC, Rfvalues and colour reactions are outlined in Table (2)

UV $\lambda$. Max in $\mathrm{MeOH}(\mathrm{nm}): 253$ (sh), 268,324 (sh), $367 \quad \mathrm{AlCl}_{3}: 266,305$ (sh), 350,422 , $\mathrm{AlCl}_{3} / \mathrm{HCl}: 266,305$ (sh), 350,422, NaOAc : 275,302 (sh) , 385, NaOAc/ $\mathrm{H}_{3} \mathrm{BO}_{3}: 267,296$ (sh), 320 (sh), 370 , NaOMe: 280, 318 (sh), 420.

UV spectral data, $\lambda$ max in $\mathrm{NaOMe}$ and shift reagents showed that:

1. Band I and II appeared at 367 and $268 \mathrm{~nm}$, respectively, which indicates that it is a flavonol type with free $\mathrm{OH}$ at position 3 .

2. Addition of $\mathrm{NaOMe}$ resulted a bathochromic shift in band I $(+63 \mathrm{~nm})$ which proved the presence of free $\mathrm{OH}$ group at position 4.

3. Bathochromic shift in band II $(+7 \mathrm{~nm})$ occurred on the addition of $\mathrm{NaOAc}$, which indicates the presence of free $\mathrm{OH}$ at position 7. Addition of boric acid gave no shift indicating the absence of orthodihydroxy group at B-ring.

4. Bathochromic shift in band $I(+53 \mathrm{~nm})$ occurred on addition of $\mathrm{AlCl}_{3}$ indicating the presence of free $\mathrm{OH}$ group at $\mathrm{C}-3$ and $\mathrm{C}-5$, this shift was not affected after the addition of $\mathrm{HCl}$ indicating the absence of orthodihydroxy group at B-ring.

${ }^{1} \mathrm{H}-\mathrm{NMR}$ spectrum of compound $\mathrm{F}_{1}$ in dimethyl sulfoxide acid DMSO-d6, showed signals at:

$\delta(\mathrm{ppm}) 8.0(2 \mathrm{H}, \mathrm{d}, \mathrm{J}=8 \mathrm{~Hz}, \mathrm{H} 2$ and $\mathrm{H} 6), \delta 6.9$ $(2 \mathrm{H}, \mathrm{d}, \mathrm{J}=8 \mathrm{~Hz}, \mathrm{H} 3$ and $\mathrm{H} 5), \delta 6.4(1 \mathrm{H}, \mathrm{d}, \mathrm{J}=$ $1.5 \mathrm{~Hz}, \mathrm{H} 8)$ and $\delta 6.2(1 \mathrm{H}, \mathrm{d}, \mathrm{J}=1.5 \mathrm{~Hz}, \mathrm{H} 6)$.

From UV analysis, compound E1 is probably kaempferol. The structure of this compound was further confirmed by ${ }^{1} \mathrm{H}$ NMR spectrum in DMSO which showed the signals characteristic for kaempferol as described by Mabry et al. (1970). 
<smiles>O=c1c(O)c(-c2ccc(O)cc2)oc2cc(O)cc(O)c12</smiles>

Kaempferol

\subsubsection{Kaempferol-3-O- $\alpha$-L-rhamnoside}

Compound $\mathrm{F}_{2}$ was obtained as yellow crystals, its m.p. $228-230^{\circ} \mathrm{C}, \mathrm{R}_{\mathrm{f}^{-}}$values and color reactions are recorded in Table (2).

UV spectral data of compound $\mathrm{F}_{2}$ in methanol and shift reagent, indicated that:

Compound $\mathrm{F}_{2}$ may be kaempferol with substitution at position 3 , as it gave band I in methanol at $350 \mathrm{~nm}$ and band II at $265 \mathrm{~nm}$, the remaining UV spectral data were found to be similar to that of kaempferol type.

A known weight of this compound was subjected to partial and complete acid hydrolysis using $0.1 \mathrm{~N}$ and $2 \mathrm{~N} \mathrm{HCl}$, afforded kaempferol as the aglycone moiety and rhamnose as the sugar moiety.

El mass spectrum revealed the presence of molecular ion peak $\mathrm{M}^{+}$at $\mathrm{m} / \mathrm{e} 433$ and other important ions m/e 303,287 (kaempferol).
From UV, acid hydrolysis, El mass spectrum and by comparison with authentic sample, compound $\mathrm{F}_{2}$ could be kaempferol-3-O- $\alpha-\mathrm{L}$ rhamnoside.<smiles>CC1OC(Oc2c(-c3ccc(O)cc3)oc3cc(O)cc(O)c3c2=O)C(O)=C(O)C1O</smiles>

Kaempferol-3-O- $\alpha$-L-rhamnoside

\subsubsection{Kaempferol 7-O-diglucoside.}

Compound $\mathrm{F}_{3}$ was obtained as yellow crystals, its m.p. $241-243{ }^{\circ} \mathrm{C}, \mathrm{R}_{\mathrm{f}^{-}}$values and colour reactions are recorded in Table (2).

UV $\lambda \max (\mathrm{nm}): \mathrm{MeOH} 256,369 ; \mathrm{NaOMe}$ decomposition; +AlCl3 267, 306sh, 360, 434; $\mathrm{AlCl} 3 / \mathrm{HCl} 265,303 \mathrm{sh}, 360,422 ;+\mathrm{NaOAc} 257$, $409 ;+\mathrm{NaOAc} / \mathrm{H}_{3} \mathrm{BO}_{3} 255,375$. NaOMe 280318 (sh), 420 .

El mass spectrum revealed the presence of molecular ion peak $\mathrm{M}^{+}$at $\mathrm{m} / \mathrm{e} 609$ (molecular ion peak, kaempferol+2 mol glucose), and other important ions m/e 287 (kaempferol).

Table (2). $\mathbf{R}_{\mathrm{f}}$-Values and color reactions of the isolated compounds.

\begin{tabular}{|c|c|c|c|c|c|}
\hline \multirow[t]{2}{*}{ Compound } & \multirow[t]{2}{*}{ Solvent system } & \multirow{2}{*}{$\begin{array}{c}\mathbf{R}_{\mathrm{r}^{-}} \\
\text {value }\end{array}$} & \multicolumn{3}{|c|}{ Color reactions } \\
\hline & & & visible & UV & UV+HN3 \\
\hline $\mathbf{F}_{1}$ & $\begin{array}{c}\text { BAW } \\
\text { Ac-OH-15\% }\end{array}$ & $\begin{array}{l}85 \\
40\end{array}$ & $\begin{array}{l}\text { Yellow } \\
\text { Yellow }\end{array}$ & $\begin{array}{l}\text { Yellow } \\
\text { Yellow }\end{array}$ & $\begin{array}{l}\text { Yellow } \\
\text { Yellow }\end{array}$ \\
\hline $\mathbf{F}_{2}$ & $\begin{array}{c}\text { BAW } \\
\text { Ac-OH-15\% }\end{array}$ & $\begin{array}{l}87 \\
50\end{array}$ & $\begin{array}{l}- \\
-\end{array}$ & $\begin{array}{l}\text { Deep purple } \\
\text { Deep purple }\end{array}$ & $\begin{array}{l}\text { Yellow } \\
\text { Yellow }\end{array}$ \\
\hline $\mathbf{F}_{3}$ & $\begin{array}{c}\text { BAW } \\
\text { Ac-OH-15\% }\end{array}$ & $\begin{array}{l}83 \\
70\end{array}$ & $\begin{array}{l}\text { Yellow } \\
\text { Yellow }\end{array}$ & $\begin{array}{l}\text { Yellow } \\
\text { Yellow }\end{array}$ & $\begin{array}{l}\text { Bright yellow } \\
\text { Bright yellow }\end{array}$ \\
\hline $\mathbf{F}_{4}$ & $\begin{array}{c}\text { BAW } \\
\text { Ac-OH-15\% }\end{array}$ & $\begin{array}{l}73 \\
29\end{array}$ & $\begin{array}{l}\text { B.yellow } \\
\text { B.yellow }\end{array}$ & $\begin{array}{l}\text { Deep purple } \\
\text { Deep purble }\end{array}$ & $\begin{array}{l}\text { Yellow } \\
\text { Yellow }\end{array}$ \\
\hline $\mathbf{F}_{5}$ & $\begin{array}{c}\text { BAW } \\
\text { Ac-OH-15\% }\end{array}$ & $\begin{array}{l}57 \\
31 \\
\end{array}$ & $\begin{array}{l}\text { Yellow } \\
\text { Yellow }\end{array}$ & $\begin{array}{l}\text { Yellow } \\
\text { Yellow }\end{array}$ & $\begin{array}{l}\text { Yellow } \\
\text { Yellow }\end{array}$ \\
\hline$\overline{F_{6}}$ & $\begin{array}{c}\text { BAW } \\
\text { Ac-OH-15\% }\end{array}$ & $\begin{array}{l}79 \\
37\end{array}$ & $\begin{array}{l}\text { Yellow } \\
\text { Yellow }\end{array}$ & $\begin{array}{l}\text { Yellow } \\
\text { Yellow }\end{array}$ & $\begin{array}{l}\text { Yellow } \\
\text { Yellow }\end{array}$ \\
\hline $\mathbf{F}_{7}$ & $\begin{array}{c}\text { BAW } \\
\text { Ac-OH-15\% }\end{array}$ & $\begin{array}{l}80 \\
60\end{array}$ & - & $\begin{array}{l}\text { Brown } \\
\text { Brown }\end{array}$ & $\begin{array}{l}\text { Brown } \\
\text { Brown }\end{array}$ \\
\hline $\mathbf{P}_{1}$ & $\begin{array}{c}\text { BAW } \\
\text { Ac-OH-15\% }\end{array}$ & $\begin{array}{l}88 \\
56\end{array}$ & - & $\begin{array}{l}\text { Bright blue } \\
\text { Bright blue }\end{array}$ & $\begin{array}{l}\text { Fl. blue } \\
\text { Fl. blue }\end{array}$ \\
\hline
\end{tabular}

$\begin{array}{llll}F_{1}-F_{7} \text { flavonoids } & P_{1} \text { phenolic compound } & B \text {. bright } & \text { Fl. fluorescence }\end{array}$ 


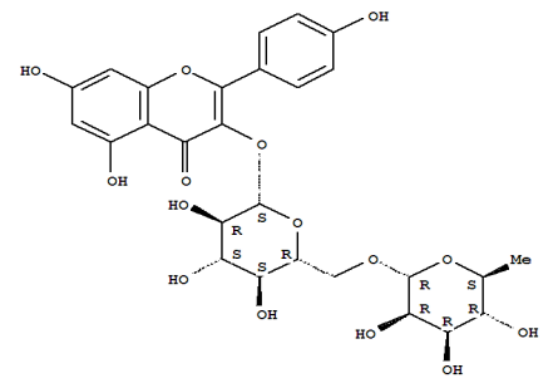

Kaempferol 7-O-diglucoside

Flavonoid $\mathrm{F}_{3}$ produced kaempferol and glucose by acid hydrolysis. UV spectral properties in addition to various shift reagents $(\mathrm{MeOH}, \mathrm{AlCl} 3, \mathrm{AlCl} 3 / \mathrm{HCl}, \mathrm{NaOAc}$, $\mathrm{NaOAc} / \mathrm{H}_{3} \mathrm{BO}_{3}$ and $\mathrm{NaOMe}$ ) according to Mabry et al. (1970) showed that $\mathrm{F}_{3}$ is 7substituted kaempferol. The attachment of $2 \mathrm{~mol}$ glucose to kaempferol was shown by MS survey, i.e., appearance of the molecular ion peak, $m / e$ 609 and fragment ion peak, $m / e$ 287. From the results described above, $\mathrm{F}_{3}$ was characterized as kaempferol 7-O-diglucoside. No bathochromic shift in band II on addition of NaOAc.

\subsubsection{Quercetin}

This compound $\left(\mathrm{F}_{4}\right)$ was obtained as yellow crystals, soluble in methanol, its m.p. 322-324 ${ }^{\circ} \mathrm{C}, \mathrm{R}_{\mathrm{f}^{-}}$values and colour reactions are recorded in Table (2).

UV. $\lambda \max (\mathrm{nm}) \mathrm{MeOH}: 258,306$ (sh), 370, $\mathrm{AlCl}_{3}: 272,328,454, \mathrm{AlCl}_{3} / \mathrm{HCl}: 268,300$ (sh), 362(sh) 428, NaOAc: 274,320 (sh), 428, $\mathrm{NaOAc} / \mathrm{H}_{3} \mathrm{BO}_{3}$ : 264, 292 (sh) 384, NaOMe: 262,332.

Compound F4 was subjected to UV spectral analysis in methanol and shift reagents. The obtained result showed that:

1- Band I in methanol appear at $370 \mathrm{~nm}$, indicating that the compounds is a flavonol type with free $\mathrm{OH}$ at position 4 .

2- The bathochromic shift in band I (+70nm) with an increase of intensity by addition of $\mathrm{NaOMe}$ indicating the presence of free $\mathrm{OH}$ at position 4.

3- The bathochromic shift occurred in band I $(+11 \mathrm{~nm})$ on addition of $\mathrm{NaOAc}$ indicating the presence of free $\mathrm{OH}$ at position 7, which deleted by $\mathrm{H}_{3} \mathrm{BO}_{3}$ addition, indicates the presence of orthodihydroxy group (3,4 position).

4- The bathochromic shift in band $\mathrm{I}(+75 \mathrm{~nm})$ appeared on addition of $\mathrm{AlCl}_{3}$ indicated the presence of 3 and 5-OH free groups.
5- The hypthochromic shift of $\mathrm{AlCl}_{3}$ spectrum in band I $(-20 \mathrm{~nm})$ after the addition of $\mathrm{HCl}$ indicates the presence of orthodihydroxy group in B-ring ( 3,4 position).

Thus from UV and $R_{f}$-values compound $F_{4}$ may be quercetin, this was confirmed by ${ }^{1} \mathrm{H}$ NMR.

Spectrum of compound $\mathrm{F}_{4}$ in DMSO- d6, showed the following signals :

$\delta(\mathrm{ppm}) 7.7(1 \mathrm{H}, \mathrm{d}, \mathrm{J}=8.5 \mathrm{~Hz}, \mathrm{H} 2), \delta 7.5(1 \mathrm{H}$, $\mathrm{dd}, \mathrm{J}=8.5, \mathrm{~J}=2.5 \mathrm{~Hz}, \mathrm{H} 6), \delta 6.8(1 \mathrm{H}, \mathrm{d}, \mathrm{J}=8.5 \mathrm{~Hz}$, $\mathrm{H} 5), \delta 6.5(1 \mathrm{H}, \mathrm{d}, \mathrm{j}=1.5 \mathrm{~Hz}, \mathrm{H} 6)$ and $\delta 6.2$ $(1 \mathrm{H}, \mathrm{d}, \mathrm{J}=1.5 \mathrm{~Hz}, \mathrm{H}-8)$.

From the previously mentioned data and by comparing with published data, (Crowford and Mabry 1978) compound $\mathrm{F}_{4}$ identified as quercetin.

\subsubsection{Quercetin-3-O- rutinoside (Rutin)}

Yellow crystals, m.p $190^{\circ} \mathrm{C} . \mathrm{R}_{\mathrm{f}}$ - values and colour reactions are recorded in Table (2).

UV $\lambda \max (\mathrm{nm}), \quad \mathrm{MeOH}: \quad 256,265(\mathrm{sh}$.$) ,$ 290,355, $\quad \mathrm{AlCl}_{3}: 274,302$ (sh.), 330 (sh.), 432, $\mathrm{AlCl}_{3}$ / HCl: 270, 298, 359, 399, NaOAc: 272, 324, 398, NaOAc $/ \mathrm{H}_{3} \mathrm{BO}_{3}: 263,292$ (sh.), 368, NaOMe: 272, 310,410. Band I in methanol at $355 \mathrm{~nm}$ indicated that this compound is a flavonol with 3-OH substitution.

${ }^{1} \mathrm{H}-\mathrm{NMR}\left(\right.$ DMSO- $\left._{6}\right): \delta 8.10(1 \mathrm{H}, \mathrm{d}, \mathrm{J}=2.5$ $\mathrm{Hz}, \mathrm{H} 2), \delta 7.86(1 \mathrm{H}, \mathrm{dd}, \mathrm{J}=8.5,2.5 \mathrm{~Hz}, \mathrm{H}-6), \delta$ $6.89(1 \mathrm{H}, \mathrm{d}, \mathrm{J}=8.5 \mathrm{~Hz}, \mathrm{H}-5), \delta 6.65(1 \mathrm{H}, \mathrm{d}, \mathrm{J}=2.5$<smiles>O=c1c(O)c(-c2ccc(O)c(O)c2)oc2cc(O)cc(O)c12</smiles>

Quercetin

$\mathrm{Hz}, \mathrm{H}-8), \delta 6.5(1 \mathrm{H}, \mathrm{d}, \mathrm{J}=2 \mathrm{~Hz} \mathrm{H} 6), \delta 5.13(1 \mathrm{H}$, $\mathrm{d}, \mathrm{J}=7.50 \mathrm{~Hz} \mathrm{H} 1$ glucose $), \delta 4.55(1 \mathrm{H}, \mathrm{d}, \mathrm{J}=2.5$ $\mathrm{Hz}, \mathrm{H} 1$ rhamnose), $\delta$ 3.47-3.87 (m, sugar protons), $\delta 1.23(3 \mathrm{H}, \mathrm{d}, \mathrm{J}=6 \mathrm{CH} 3)$.

${ }^{13} \mathrm{C}-\mathrm{NMR}$ (methanol- $\mathrm{D}_{6}$ ): $\delta$ ppm $174.3(\mathrm{C}-4)$, 164.5 (C-4), 164.5 (C-7), 161.2 (C-5), 156.6 and 156.4 (C-2 and C-9 respectively), 148.5 (C-4), 144.8 (C-3), 133.3 (C-3), 121.6 (C-6), 121.2 (C1), 116.1 (C-2), 115.2 (C-5), 103.8 (C-10), 98.8 and 93.7 (C-6 and C-8, respectively), 100.7 (C1"), 76.5 (C-3), 75.9 (C-5),74.1 (C-2), 71.5 (C-4), 62.8 (C-6), 101.3 (C-1), 71.9 (C-4), 70.6 (C-2), 70.4 (C-3), 70 (C-5) and 17.6 (C-6). 


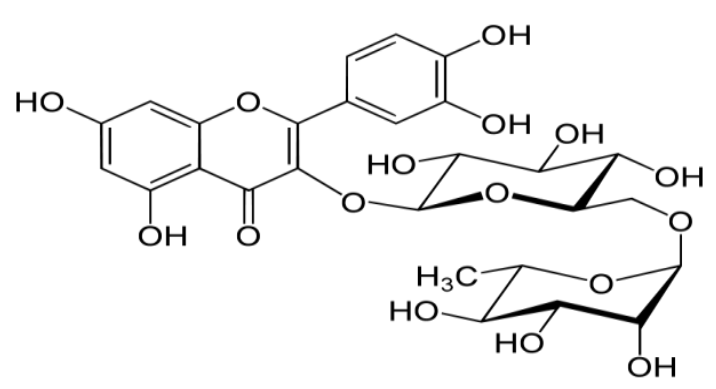

Quercetin-3-O- rutinoside

\subsubsection{Quercetin-3-rhamnoside}

Yellow crystals, mp. $224-226^{\circ} \mathrm{C}, \mathrm{R}_{\mathrm{f}^{-}}$values and colour reactions are recorded in Table (2).

UV $\lambda \max (\mathrm{nm}) \mathrm{MeOH}: 260.358 \quad \mathrm{AlCl}_{3}$ : 272,300 (sh.), 440, AlCl3 / HCl: 272, 300 (sh.), $420 \mathrm{NaOAc:} 275.300$ (sh.), $395 \mathrm{NaOAc} / \mathrm{H}_{3} \mathrm{BO}_{3}$ : 260,325 (sh), 375, NaOMe: 272,320 (sh.), 430.

${ }^{1} \mathrm{H}-\mathrm{NMR}$ - (DMSO- $\left.\mathrm{d}_{6}\right): \delta 7.7(1 \mathrm{H}, \mathrm{d}, \mathrm{J}=2.5$ $\mathrm{Hz}, \mathrm{H} 2), \delta 7 . \overline{5}(1 \mathrm{H}, \mathrm{dd}, \mathrm{J}=8.5,2.5 \mathrm{~Hz}, \mathrm{H} 6)$

$\delta 6.8(1 \mathrm{H}, \mathrm{d}, \mathrm{J}=8.5, \mathrm{H} 5), \delta 6.5(1 \mathrm{H}, \mathrm{d}, \mathrm{J}=2.5$ $\mathrm{Hz}, \mathrm{H} 8), \delta 6.2(1 \mathrm{H}, \mathrm{d}, \mathrm{J}=2.5 \mathrm{~Hz}, \mathrm{H} 6), \delta 5.4(1 \mathrm{H}$, $\mathrm{d}, \mathrm{J}=2 \mathrm{~Hz}, \mathrm{H} 1$ rhamnose), $\delta$ 3.5-4 (m, sugar protons) and $\delta 1.2(3 \mathrm{H}, \mathrm{d}, \mathrm{J}=6 \mathrm{~Hz}, \mathrm{CH} 3$ rhamnose).

\subsubsection{Quercetin-3-O-glucoside}

This compound $\left(\mathrm{F}_{7}\right)$ was found to be yellow crystals, its mp. $228-230^{\circ} \mathrm{C}, \mathrm{R}_{\mathrm{f}^{-}}$values and colour reactions are recorded in Table(2).

UV spectral data of compound $F_{7}$ in methanol and shift reagent, from which it can concluded that: Compound $\mathrm{F}_{7}$ may be quercetin with substitution at position 3. UV $\lambda \max (\mathrm{nm})$ $\mathrm{MeOH}:$ 265,350, AlCl3: 265, 300 (sh) 440, $\mathrm{AlCl} 3 / \mathrm{HCl}: 265$, 350, 420, NaOAc: 270,300,380, NaOAc/H3BO3: 270, 310, 373, NaOMe: 275, 330,430 .

${ }^{1} \mathrm{H}-\mathrm{NMR} \_\left(\mathrm{DMSO}-\mathrm{d}_{6}\right): \delta 7.2(2 \mathrm{H}, \mathrm{d}, \mathrm{J}=8 \mathrm{~Hz}, \mathrm{H} 2$ and $\mathrm{H} 6), \delta 6.8(2 \mathrm{H}, \mathrm{d}, \mathrm{J}=8 \mathrm{~Hz}, \mathrm{H} 3$ and $\mathrm{H} 5), \delta 5.8$ $(1 \mathrm{H}, \mathrm{d}, \mathrm{J}=2.5 \mathrm{~Hz}, \mathrm{H} 8), \delta 5.7(1 \mathrm{H}, \mathrm{d}, \mathrm{J}=2.5 \mathrm{~Hz}$, H6), $\delta 5.4(1 \mathrm{H}, \mathrm{d}, \mathrm{J}=\mathrm{Hz}, \mathrm{H} 1$ glucose).

From UV, ${ }^{1} \mathrm{H}-\mathrm{NMR}$ spectrum and by comparison with authentic sample, compound $\mathrm{E}_{6}$ could be identified as quercetin-3- glucoside.<smiles>O=c1cc2oc(c1Oc1c(-c3ccc(O)c(O)c3)oc3cc(O)cc(O)c3c1=O)C(O)=C(O)C=C2O</smiles>

Quercetin 3-O-glucoside (Isoquercitrin, 3).

\subsubsection{Ferulic acid}

This compound is soluble in benzene, chloroform and methanol. $\mathrm{R}_{\mathrm{f}}$ values and color reactions of the compound $\mathrm{P}_{2}$ were recorded in Table (2).

From UV spectral data of the compound $\mathrm{P}_{2}$ exhibited absorption band I and II (285 and 312) which were characteristic of phenyl propanoids.

Bathochromic shift after addition of $\mathrm{NaOMe}$ in band I and II (345 and $290 \mathrm{~nm}$, respectively) proved the presence of free $\mathrm{OH}$.

The $R_{f^{-}}$values, color reactions and $\mathrm{UV}$ spectral data proved that, the compound $\mathrm{P}_{2}$ seemed to be phenolic in nature and contain the free $\mathrm{OH}$.

The ${ }^{1}$ H-NMR spectral data (Table 2) showed two doublets at $\delta 7.54$ and $6.25 \mathrm{ppm}, \mathrm{J}=17 \mathrm{~Hz}$ which are characteristic for trans olefinic double band (H-7 and $\mathrm{H}-8)$, respectively. The presence of two doublets at $\delta 7.15$ and 6.95 and the doublet of doublet signal at $\delta 7.09$ are corresponding to ortho and meta coupling which is a good evidence for the presence of trisubstituted benzene. The presence of singlet at $\delta 8.9$ confirmed the UV analysis for the presence of free $\mathrm{OH}$ group. The presence of a signal at $\delta$ 3.85 for- $\mathrm{OCH}_{3}$ group.

From the previous obtained data, the compound $\mathrm{P}_{2}$ was identified as ferulic acid (4hydroxy-3-methoxy).

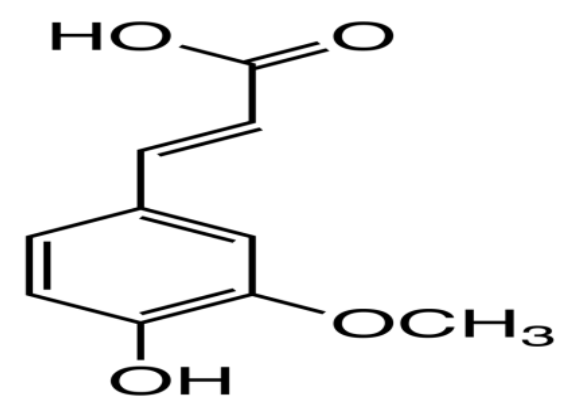

Ferulic acid

\section{REFERENCES}

Anderson R.A. and Sowers I.A.(1998).Flavonoid separation by paper chromatography, Phytochem., 11(8): 2601- 2603.

Crawford D.J. and Mabry T.J. (1978). Flavonoid chemistry of Chenopodium fremontii. Biochem. Syst. Ecol. 6 (3): 189192.

El Ansari M. A., Nawwar M. A. M., El Dein A., El Sherbeiny A. and El Sissi H. I.(1976).A sulphated kaempferol7,4'-dimethyl ether and a quercetin isoferulylglucuronide 
from the flowers of Tamarix aphylla. Phytochem. 15: 231-232.

El Sissi H. I., Nawwar M. A. M. and Saleh N. A. M.(1973). Plant constituents of Tamarix nilotica leaves (Tamaricaceae). Exper. 29: $1064-1065$.

Harborne J. B. (1975). Flavonoid bisulphates and their cooccurrences with ellagic acid in the Bixaceae, Frankeniaceae and related families. Phytochemistry, 14: 1331- 1337.

Harborne J.B., Mabry T.J. and Mabry H. (1975). The flavonoids. Chapoman and Hall,London: 1204pp.

Karawya M.S and Aboutable E.A. (1982). Phytoconstituents of tabernaemontana coronaria Jac .Q.willed and dichotoma roxii B.growing in Egypt . part .IV: the flavonoids. Bull. Fac. Pharma, Cairo Univ., 21 (1) :41- 49.

La X., Zeng Y., Xu M. and Zhang Y. (2011). Flavonoids from the twigs of the Tibetian medicine Myricaria germanica. Nat.. Prod. Res. and Develop., 23: 596-599.

Lee D.H., Ku C.H., Baek N., Kim S., Park H.W. and Kim D.K. (2004). Phytochemical constituents from Diodia teres, Arch . Pharm. Res, 27(1): 40-43.

Mabry T.J., Markam K. R. and Thomas M. B. (1970): The systematic identification of flavonoids. Springer Verlag, New York. USA, 2204 pp.

Nawwar M. A. M., El Sherbieny A. and El Ansari M. A. (1975). Plant constituents of
Tamarix aphylla flowers (Tamaricaceae). Exper., 31: 1118- 1124.

Nawwar M. A. M., Ishak M. S., El Din A., El Sherbieny A. and Meshaal S. A. (1977). Flavonoids of Reaumuria mucronata and Thymelaea hirsuta. Phytochem, 16:13191320.

Nawwar M. A. M., Souleman A. M. A., Buddrus J. and Linscheid M. (1984). Flavonoids of the flowers of Tamarix nilotica. Phytochem, 23: 2347-2349.

Saleh N. A. M., El-Sissi H. I. and Nawwar M. A. M.(1975). A rhamnetin glucuronide trisulphate from the leaves of Tamarix aphylla. Phytochem . 14: 312-313.

Tomás-Barberán F. A., Iniesta-Sanmartín E., Ferreres F., Tomás-Lorente F., Trowitzsch-Kienast W. and Wray V. (1990). Trans-coniferyl alcohol 4-Osulphate and flavonoid sulphates from some Tamarix species. Phytochem., 29: 3050-3051.

Tsukasa I.w., Sergey V.S., Oyunchimeg D. and Katsuhiko K. (2012). Flavonoids from Reaumuria soongarica (Tamaricaceae) in Mongolia. Bull. Natl. Mus. Nat. Sci., Ser. B., 38(4): 189-195.

Wang B., Ren S., Li G. and Guan H. (2009). Studies on antitumor steroids and flavonoids from Tamarix chinensis Lour. Chinese Pharmaceut, 44:576- 580.

Yang G. and Gaskin J. (2006). Tamaricaceae. Flora of China, 13: 58-69.

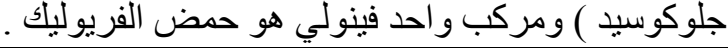

